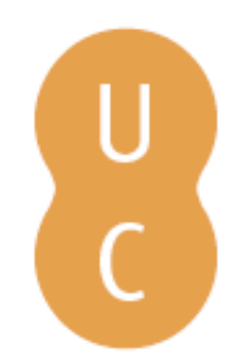

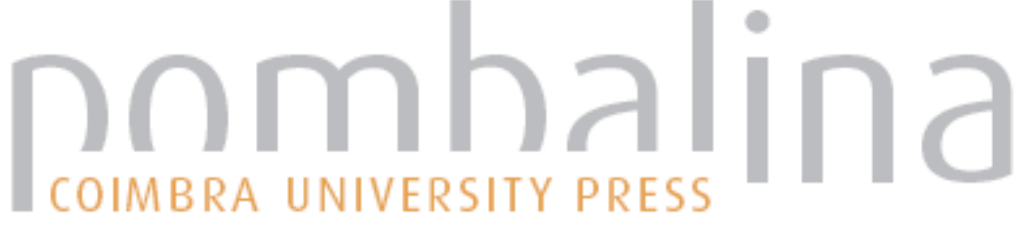

\section{Hematúria e Proteinúria}

Autor(es): $\quad$ Correia, António Jorge

Publicado por: Imprensa da Universidade de Coimbra

URL

persistente: URI:http://hdl.handle.net/10316.2/43135

DOI: $\quad$ DOI:https://doi.org/10.14195/978-989-26-1300-0_34

Accessed : $\quad$ 26-Apr-2023 09:45:23

A navegação consulta e descarregamento dos títulos inseridos nas Bibliotecas Digitais UC Digitalis, UC Pombalina e UC Impactum, pressupõem a aceitação plena e sem reservas dos Termos e Condições de Uso destas Bibliotecas Digitais, disponíveis em https://digitalis.uc.pt/pt-pt/termos.

Conforme exposto nos referidos Termos e Condições de Uso, o descarregamento de títulos de acesso restrito requer uma licença válida de autorização devendo o utilizador aceder ao(s) documento(s) a partir de um endereço de IP da instituição detentora da supramencionada licença.

Ao utilizador é apenas permitido o descarregamento para uso pessoal, pelo que o emprego do(s) título(s) descarregado(s) para outro fim, designadamente comercial, carece de autorização do respetivo autor ou editor da obra.

Na medida em que todas as obras da UC Digitalis se encontram protegidas pelo Código do Direito de Autor e Direitos Conexos e demais legislação aplicável, toda a cópia, parcial ou total, deste documento, nos casos em que é legalmente admitida, deverá conter ou fazer-se acompanhar por este aviso.

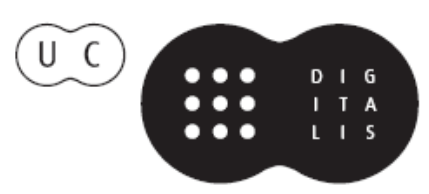




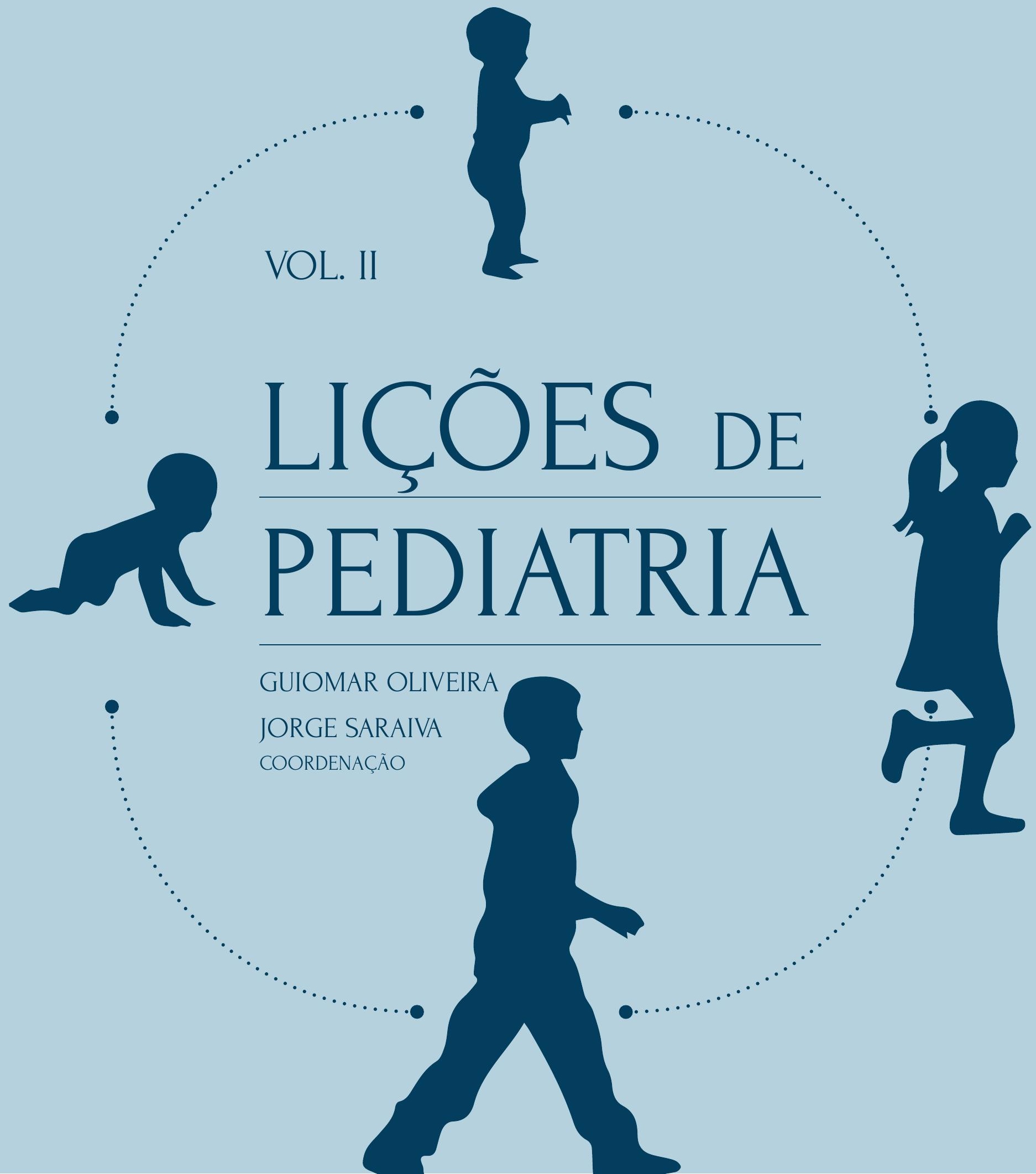


Capítulo 34.

Hematúria e Proteinúria

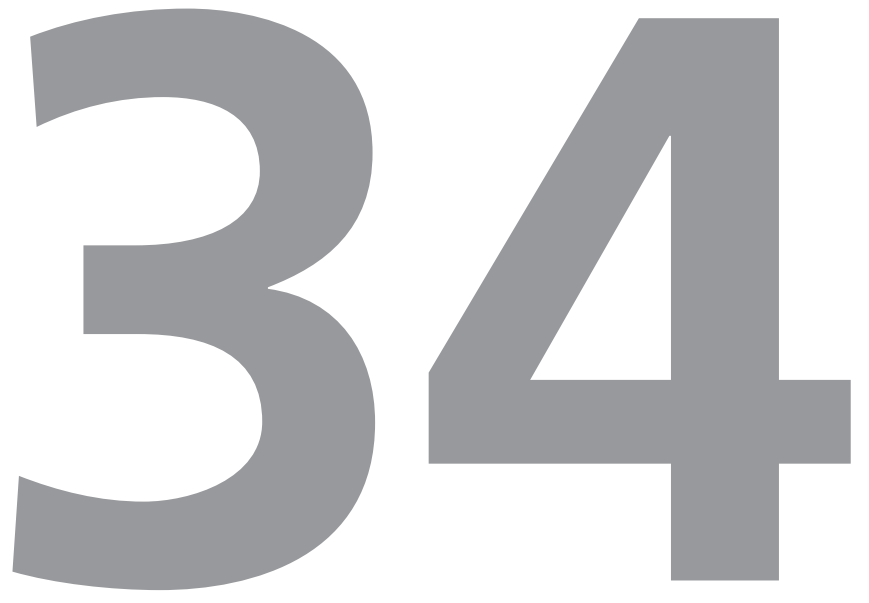

António Jorge Correia 


\subsection{CONTEXTO}

Na criança a presença de hematúria ou proteinúria pode ser transitória surgindo muitas vezes em situações febris e acompanhando infeções virusais. A hematúria macroscópica ou o achado acidental de hematúria ou proteinúria na tira reagente urinária é um sinal alarmante para os pais.

A presença de hematúria associada a proteinúria é um marcador significativo de doença glomerular, assim como de doença renal crónica.

Enquanto a orientação da criança com hematúria e proteinúria ou alteração da função glomerular é consensual, a orientação da criança com hematúria microscópica isolada é motivo de contínuo debate.

\subsection{DESCRIÇÃO DO TEMA}

\subsubsection{Hematúria}

Hematúria significa a presença de glóbulos vermelhos (GV) na urina em quantidade superior ao normal. Pode ser microscópica ou macroscópica e a sua origem encontrar-se em qualquer ponto do aparelho urinário.

A prevalência da hematúria microscópica assintomática varia entre 0.5 a $1.6 \%$ nas crianças em idade escolar. A hematúria pode indicar ou não a presença de doença renal. A Academia Americana de Pediatria recomenda o seu rastreio na idade escolar, entre os quatro e os cinco anos de idade, e durante a adolescência entre os 11 e os 21 anos. Não existe consenso na definição de hematúria microscópica. A definição mais aceite corresponde à presença superior a cinco
GV/campo (objetiva de 400x) em $10 \mathrm{ml}$ de urina fresca centrifugada ou mais de cinco $\mathrm{GV} / \mathrm{mm}^{3} \mathrm{em}$ urina fresca não centrifugada, em três amostras consecutivas, separadas entre si por um período de tempo de duas a quatro semanas.

A hematúria macroscópica define-se pela presença mais de $5.000 \mathrm{GV} / \mathrm{mm}^{3}$, podendo na apresentação clínica ter uma coloração de sangue vivo, cor de tijolo ou "coca-cola". É menos frequente que a hematúria microscópica na idade pediátrica.

A morfologia dos GV ajuda a identificar a origem da hematúria, sendo que o predomínio de eritrócitos dismórficos é indicador de proveniência glomerular.

Um conjunto de causas pode originar urina vermelha sem haver hematúria: hemoglobinúria, mioglobinúria, vários medicamentos (como a rifampicina), corantes alimentares, doenças metabólicas (como a porfiría), presença de cristais de uratos e a hematúria do Síndrome de Münchausen «by proxy» («por procuração»), situação rara, que ocorre quando um parente, quase sempre a mãe (85 a 95\%), de modo persistente ou intermitente simula de forma intencional hematúria no seu filho.

As tiras reagentes urinárias $\left(C\right.$ ombur $\left.{ }^{R}\right)$ permitem a determinação qualitativa, são usadas de rotina no diagnóstico de hematúria microscópica e são altamente sensíveis (mais para a hemoglobina livre do que para os eritrócitos). A sensibilidade é de 91 a 100\% para identificar dois a cinco GV/ campo (400x) e a especificidade de 65 a 99\%. Os falsos negativos são raros (urina muito ácida, presença de substâncias redutoras como o ácido ascórbico e deterioração das tiras). Os falsos positivos surgem na presença de hemoglobinúria (anemias hemolíticas, hemoglobinopatias, 
hemoglobinúria paroxística e da marcha, queimaduras...), mioglobinúria (traumatismos, convulsões generalizadas, exercício físico intenso, eletrocussão, insolação, drogas como a heroína e anfetaminas, venenos...), presença de peroxidases bacterianas e leituras tardias.

A identificação de reação positiva ao sangue em tira reagente, exige sempre confirmar a presença de GV no estudo microscópico. A urina mais fiável é a primeira urina da manhã, colhida a meio do jato, evitando exercício físico intenso 48 horas antes da colheita e analisando a urina em menos de uma hora após a colheita.

Factos a reter no exame da urina:

- É importante confirmar que a urina vermelha é devida a hematúria, pela demonstração de GV no exame microscópico.

- A presença de cristais de uratos na urina de lactentes, pode causar uma coloração rosa nas fraldas, mas não é hematúria, nem tem significado clinico.

- A hematúria do Síndrome de Münchausen «by proxy» deve ser considerada no diagnóstico diferencial.

Uma vez confirmada a existência de hematúria é importante localizar a origem glomerular ou não glomerular da mesma, que permitirá não só estabelecer a etiologia, como também orientará a investigação posterior.

Factos a reter no exame

microscópico da urina:

- A morfologia dos GV pode ajudar a identificar a origem da hematúria: GV dismórficos indicam hematúria de causa glomerular.

- A presença de cilindros eritrocitários é patognomónica de hematúria de causa glomerular.

- A presença de cilindros leucocitários significa inflamação glomerular.

- A urina normal pode conter cristais de fosfato de cálcio e oxalato de cálcio.

A hematúria macroscópica acompanha-se sempre de proteinúria, geralmente discreta devido à presença de proteínas plasmáticas. Quando se associa a proteinúria marcada $(+++/++++)$ sugere etiologia glomerular.

A fase da micção em que surge a hematúria macroscópica pode informar quanto à sua origem no aparelho urinário. Se a hematúria surge no início da micção (hematúria inicial) e tem uma coloração de sangue vivo, corresponde a lesão sangrante da uretra. A hematúria que surge no final da micção (hematúria terminal) de coloração sangue vivo corresponde, em regra, a lesão sangrante da bexiga (trígono). Se a hematúria persiste em toda a micção (hematúria total), poderá ter etiologia renal, ureteral ou corresponder a lesão sangrante da bexiga como a cistite hemorrágica causada por vírus (adenovirus).

\section{A infeção do trato urinário é a causa} mais comum de hematúria macroscópica na idade pediátrica.

A hematúria macroscópica de causa glomerular tem cor castanho uniforme, que é comparada a "coca-cola" ou cor de tijolo, não apresenta coágulos, o sedimento revela a presença 
de cilindros hemáticos e os eritrócitos são na sua maioria dismórficos (acima de 80\%). Associa-se com frequência a proteinúria $(>++)$.

A hematúria macroscópica de causa extraglomerular tem coloração de sangue vivo ou rosa, a sua cor pode não ser uniforme e serem visíveis coágulos, não existindo ao exame microscópico da urina cilindros hemáticos e os eritrócitos dismórficos são raros ou inexistentes (abaixo de 20\%).

Factos a reter na hematúria macroscópica:

- A infeção do trato urinário é a causa mais comum de hematúria macroscópica.

- Na presença de hematúria macroscópica deve-se iniciar uma investigação urgente.

- A hematúria induzida pelo exercício físico não está associada a doença renal.

- Se associada a alteração da função glomerular, proteinúria ou hipertensão arterial a orientação deve ficar a cargo de nefrologista pediátrico.

\section{A hematúria microscópica assintomá-}

tica isolada é a forma de apresentação mais frequente, muitas vezes descoberta num exame de urina com tira reagente. É necessário confirmar a hematúria através de exame microscópico e comprovar a sua existência em três amostras obtidas com intervalo de duas a quatro semanas. Se a avaliação inicial destas crianças não revela o diagnóstico etiológico, recomenda-se um período de seguimento de um a dois anos apenas com exame de urina, para determinar se persiste a hematúria microscópica, antes de prosseguir estudo com exames mais invasivos. A relação cálcio/ creatinina da urina, permite avaliar se existe hipercalciúria. Se a hematúria microscópica se associa a hipertensão arterial, doença renal crónica ou proteinúria, deve ser investigada de forma rápida.

Na hematúria microscópica assintomática com proteinúria deve-se avaliar o grau da proteinúria quantitativamente, proteinúria em $\mathrm{mg} / \mathrm{metro}^{2} / \mathrm{hora}\left(\mathrm{mg} / \mathrm{m}^{2} / \mathrm{h}\right)$ ou qualitativamente através da relação Proteinas $_{\text {urina }} /$ Creatinina $_{\text {urina }}$ $\left(\operatorname{Prot}_{\mathrm{u}} / \mathrm{Cr}_{\mathrm{u}}\right)$. Se a proteinúria for de nível nefrótico (> $40 \mathrm{mg} / \mathrm{m} 2 / \mathrm{h}$ ou Protu/Cru> 200 mg/ $\mathrm{mmol}$ ) orienta para origem glomerular. Se for de nível ligeiro ou moderado pode ter origem tubulointersticial ou vascular. Na hematúria microscópica sintomática as manifestações clínicas associadas podem ser gerais (febre, mal estar, dor abdominal), inespecíficas (exantema, púrpura, artrite, icterícia, alterações respiratórias ou gastrointestinais) ou específicas do aparelho urinário (sintomas micionais, enurese, edema, hipertensão arterial).

Factos a reter na hematúria microscópica:

- Só cerca de 30\% das crianças continua a ter hematúria microscópica seis meses após o achado inicial.

- A criança com hematúria microscópica associada a insuficiência renal, proteinúria significativa ou hipertensão tem risco de ter uma causa preocupante devendo ser referenciada ao nefrologista pediátrico e investigada de forma rápida.

- A etiologia da hematúria varia em função da idade.

- As causas de hematúria dividem-se habitualmente em dois grandes grupos: glomerular e não glomerular, renal e extra-renal, quadro 1. 


\begin{tabular}{|c|c|}
\hline Iria Glomerular & Hematúria não glomerular \\
\hline $\begin{array}{l}\text { Doenças Sistémicas } \\
\text { - Púrpura de Henoch-Schönlein } \\
\text { - Síndrome hemolítico-urémico } \\
\text { - Lúpus eritematoso sistémico } \\
\text { - Outras }\end{array}$ & $\begin{array}{l}\text { Renal } \\
\text { 1. Nefropatia intersticial } \\
\text { - Infeciosa (pielonefrite aguda, tuberculose renal) } \\
\text { - Metabólica (cálcio, oxalato, ácido úrico) } \\
\text { - Tóxica (fármacos, outros tóxicos) } \\
\text { - Necrose tubular } \\
\text { 2. Doenças quísticas renais } \\
\text { 3. Patologia vascular } \\
\text { - Trombose, malformações dos vasos renais } \\
\text { - Drepanocitose } \\
\text { 4. Traumatismos } \\
\text { 5. Tumores } \\
\text { - Wilms, nefroma mesoblástico }\end{array}$ \\
\hline
\end{tabular}

Quadro 1. Diagnóstico diferencial entre hematúria glomerular versus não glomerular.

O diagnóstico de hematúria na criança tem como objetivo confirmar a sua existência, identificar a causa e reconhecer a gravidade do processo, identificando alterações com risco de vida para o doente e que requerem atuação urgente (hipertensão arterial, insuficiência renal aguda) e eliminar causas que possam originar deterioração renal progressiva e/ou irreversível (uropatias malformativas, tumores).

Uma história clínica detalhada e precisa com uma análise de urina e do sedimento urinário dão informações que permitem localizar a hematúria (trato urinário alto versus baixo) e a urgência da avaliação. 
Na anamnese saber se exitem antecedentes de hematúria em familiares próximos, consanguinidade, surdez, quistos renais, litíase, hipertensão arterial, insuficiência renal crónica (IRC), doenças hematológicas (drepanocitose, coagulopatias). Não esquecer de realizar sempre a análise de urina aos pais e irmãos através de tira reagente. Nos antecedentes pessoais procurar antecedentes neonatais (trombose renal, cardiopatia congénita...), infeções urinárias prévias, medicação habitual, tipo de exercício que pratica e história de traumatismo ou extração dentária.

Na anamnese saber as características da hematúria (cor, relação com a micção, duração), circunstâncias acompanhantes (traumatismo abdominal ou lombar, exercício físico prévio, antecedentes de infeção respiratória ou cutânea prévia, disúria).

No exame físico avaliar crescimento (peso, estatura e evolução estato-ponderal), tensão arterial, presença de edemas, manifestações cutâneas hemorrágicas (petéquias, equimoses), exantemas, sinais de cardiopatia, ascite, globo vesical, massas abdominais, genitais externos (balanite, dermatite das fraldas), artralgia, presença de sinais de artrite e alterações da marcha.

É essencial investigar a hematúria de modo a identificar a causa. Na investigação nem todos os exames laboratoriais estão indicados na primeira fase. A análise de urina é o exame de primeira linha, incluindo o aspecto macroscópico, a tira reagente (pesquisa de glicose, proteínas, nitritos) e o estudo microscópico do sedimento urinário. Se a hematúria se associa a sintomas de infeção do trato urinário, realizar também a urocultura para confirmar o diagnóstico.

Na presença de hematúria sem antecedentes familiares de IRC, se a proteinúria é mínima ou ausente e se o exame do sedimento urinário não apresenta GV dismórficos, a hematúria não tem origem glomerular. Se a criança tem hematúria e sintomas sugestivos de cólica renal a ecografia ou a tomografia axial computorizada (TAC) permitem confirmar o diagnóstico de litíase. O doseamento na urina de 24 horas da excreção aumentada de várias substâncias (cálcio, oxalatos, cistina...) permite identificar causas de litíase.

Se a hematúria é macroscópica, persiste e não se confirmou infeção urinária: pesquisar antigénios estreptocócicos e cultura do exsudato da orofaringe, realizar hemograma e reagentes de inflamação de fase aguda como a proteína $C$ reativa e a velocidade de sedimentação, estudo da coagulação, ureia, creatinina, ionograma, ácido úrico, proteínas totais, albumina, colesterol, transaminases, estudo imunológico (titulo de antiestreptolisina O, C3 e C4) e ecografia renal (exame imagiológico de primeira linha).

Se existe uma história recente de traumatismo, está indicado um estudo imagiológico do trato urinário (ecografia, TAC). De acordo com a evolução clínica e caso a caso, ponderar a realização de outros exames complementares.

A causa mais frequente de hematúria microscópica persistente na criança é a hematúria familiar benigna, que tem bom prognóstico a longo prazo.

Na presença de hematúria sem antecedentes familiares de IRC, se a proteinúria é nefrótica, a hematúria tem origem glomerular. As crianças com hematúria microscópica e hipertensão, história familiar de doença renal e proteinúria significativa ou nefrótica, podem ter indicação para biópsia renal. 
Factos a reter na avaliação de uma criança com hematúria:

- Confirmar a existência de hematúria verdadeira.

- Na avaliação da hematúria ter em consideração se é microscópica ou macroscópica, a história recente da criança, sintomas associados e o exame físico.

- Uma investigação adequada é essencial para identificar a etiologia, em particular se a hematúria é macroscópica, sintomática, associada a proteinúria, com alteração da função glomerular ou hipertensão.

- Avaliação clínica minuciosa (história clínica e um exame cuidadoso) para identificar possíveis causas e investigação adequada. O tratamento depende da causa.

- Identificar doentes que necessitam de orientação para a nefrologia pediátrica.

\subsubsection{Proteinúria}

Proteinúria é a perda excessiva de proteínas na urina e pode indicar lesão renal ou ser apenas um achado laboratorial. A presença de proteinúria em crianças assintomáticas é frequente em pediatria. Pode ser transitória ou persistente. A primeira é uma condição benigna que não requer mais investigações e pode estar presente em situações como febre, atividade física intensa e stresse, enquanto a segunda pode ser um sinal importante e precoce de disfunção renal e indicia risco de progressão da glomerulopatia.

A perda urinária excessiva de proteínas está relacionada com uma perturbação da sua filtração ou reabsorção. Em condições normais, os capilares glomerulares limitam a filtração de macromoléculas pelo seu tamanho molecular e pela sua carga elétrica. As proteínas de maior peso molecular não aparecem (globulinas) ou aparecem em quantidades muito pequenas no filtrado glomerular, enquanto as de menor peso molecular são parcialmente filtradas. A maior parte destas proteínas é reabsorvida no túbulo proximal.

A proteinúria intensa origina hipoproteinémia, diminuição da pressão oncótica vascular e perda de líquido do espaço intravascular para o extravascular e manifesta-se principalmente por edema. O edema pode ser localizado ou generalizado (anasarca). Os locais em que mais precocemente surge o edema de causa renal são as pálpebras, membros inferiores e escroto nos rapazes.

As tiras reativas são um método qualitativo de pesquisa de proteinúria, que determina a concentração de albumina por reação colorimétrica com tetrabromofenol, mudando de cor amarela para diferentes intensidades de verde que se comparam com uma escala. A sua relação aproximada é: vestígios (15 a 30 mg/dl), 1+ (30 a $100 \mathrm{mg} / \mathrm{dl}), 2+(100$ a $300 \mathrm{mg} / \mathrm{dl}), 3+(300 \mathrm{a}$ $1000 \mathrm{mg} / \mathrm{dl})$ e $4+(>1000 \mathrm{mg} / \mathrm{dl})$. As maiores vantagens das tiras reativas são a comodidade de utilização e o resultado imediato, e os inconvenientes são não detetar proteínas de baixo peso molecular (teste negativo nas proteinúrias tubulares). Os falsos positivos acontecem em situações de urina alcalina, presença de antisséticos (clorohexina, detergentes) e contrastes radiológicos iodados. A urina diluída pode ser causa de falsos negativos.

A determinação quantitativa da proteinúria com ácido sulfossalicílico é um método 
colorimétrico com maior sensibilidade que as tiras reativas (5 a $10 \mathrm{mg} / \mathrm{dl}$ ) e que deteta todo o tipo de proteínas. Tem falsos positivos: urina muito concentrada, contrastes radiológicos e medicamentos (penicilinas, cefalosporinas, sulfamidas e tolbutamida). Os falsos negativos são: urina muito diluída ou muito alcalina. Para pesquisar proteinúria tubular ou microalbuminúria são necessários métodos específicos como técnicas de radioimunoanálise ou nefelometria.

\section{Proteinúria fisiológica:}

Considera-se fisiológica uma eliminação até $100 \mathrm{mg} / \mathrm{m}^{2} / \mathrm{dia}$ ou $<4 \mathrm{mg} / \mathrm{m}^{2} /$ hora. Quando existe dificuldade em obter uma colheita de urina de 12 ou 24 horas pode utilizar-se a relação proteínas/creatinina numa amostra isolada de urina, de preferência a primeira urina da manhã, considerando-se valores normais: <0.2 ( $\mathrm{mg} / \mathrm{mg})$ ou $<20$ ( $\mathrm{mg} / \mathrm{mmol})$.

\section{Microalbuminúria:}

A eliminação normal de albumina é de 5 a $30 \mathrm{mg} / \mathrm{dia} / 1.73 \mathrm{~m}^{2}$. A partir deste valor até 300 mg considera-se microalbuminúria patológica. Acima deste valor define-se como albuminúria. A dificuldade na recolha de urina por períodos de 8 a 24 horas, fez com que a determinação da relação microalbumina/creatinina (nas unidades de $\mu \mathrm{g} / \mathrm{mg}$ ), que se correlaciona bem com a determinação das perdas em 24 horas, seja utilizado como método de rastreio. A microalbuminúria pode estar presente de forma transitória em situações de febre, exercício e insuficiência cardíaca. Valores persistentemente elevados significam lesão glomerular incipiente, pelo que a determinação é muito importante no controlo de doentes diabéticos, hipertensos e com redução da massa glomerular.

Existem quatro mecanismos para a excreção excessiva de proteínas na urina: aumento da filtração glomerular, inadequada reabsorção tubular, por sobrecarga (overflow) e aumento da secreção tubular. Segundo a sua origem a proteinúria classifica-se em glomerular, tubular e por sobrecarga de filtração.

Designa-se a proteinúria de seletiva, se a percentagem de albumina na urina é superior a $85 \%$ do total da proteinúria. A proteinúria não seletiva deve-se a lesões renais mais graves.

\section{Proteinúria transitória:}

É muito frequente variando a sua incidência entre 5 e $15 \%$ das crianças. Pode surgir nos síndromes febris, exercícios violentos, convulsões, insuficiência cardíaca, de entre outros, mas pode ocorrer sem causa desencadeante aparente, não se associa a edema e raramente é superior a 1000 mg/dL. Isolada não tem significado patológico.

\section{Proteinúria ortostática:}

Define-se como o aumento da excreção de proteínas na urina na posição ortostática, mas com excreção normal nas amostras recolhidas após repouso e decúbito. Surge em adolescentes com hiperlordose em ortostatismo prolongado e ocorre em 2 a 5\% dos adolescentes (rara após os 30 anos). Não implica mau prognóstico a não ser que se associe a hipertensão ou a alterações do sedimento urinário.

\section{Proteinúria persistente:}

Pode ter origem glomerular (primária ou secundária), origem tubular ou de sobrecarga 
de filtração (rara em pediatria). A principal causa de proteinúria glomerular grave ou nefrótica na criança é o síndrome nefrótico de lesões glomerulares mínimas. Menos frequentes são outras causas como: glomeruloesclerose segmentar e focal, glomerulonefrite membranosa, mesangial, pós-estreptocócica, nefropatia a lgA, e nefrite em contexto de infeção por vírus da imunodeficiência humana (VIH) ou da hepatite B. Nos lactentes considerar como causa provável os sindromes nefróticos congénitos tipo finlandês e a esclerose mesangial. O lúpus eritematoso sistémico, a púrpura de Henoch-Shönlein, as vasculites e os quadros autoinflamatórios, podem ser causa de proteinúria na criança.

A biópsia renal em crianças com proteinúria isolada está indicada se a proteinúria for superior a $500 \mathrm{mg} / \mathrm{m}^{2} / \mathrm{dia}$, excluída a proteinúria ortostática ou quando surge hipertensão arterial ou alterações da função renal.

São causas de proteinúria tubular primária: proteinúria tubular isolada, familiar ou esporádica, associada a hipercalciúria (sindrome de Dent), sindrome de Fanconi primário. São causas de proteinúria tubular secundária: sindrome de Fanconi secundário, doença poliquística, doença mitocondrial, intoxicação por metais pesados, nefrite túbulo-intersticial, uropatias obstrutivas e necrose tubular aguda.

Na avaliação da criança com proteinúria começar por realizar uma história clínica e exame físico orientados para determinar a etiologia. A proteinúria que surge durante um episódio febril, depois de exercício físico intenso, no contexto de uma convulsão, situações de stresse ou cirurgia recente é sugestiva de proteinúria transitória. Alterações na cor da urina e do volume da diurese, presença de edemas, hipertensão arterial, infeção estreptocócica recente ou história familiar de doença renal sugerem uma doença renal subjacente com proteinúria persistente. Outros sinais ou sintomas como febre, púrpura, exantemas, artrite, dor abdominal são sugestivos de uma nefropatia associada a uma doença sistémica.

A primeira atitude perante o achado de proteinúria numa tira reativa é repetir a análise de urina. Muitas vezes o episódio de proteinúria é transitório. Confirmada a proteinúria em duas análises de urina, se a criança está assintomática, realizar teste da proteinúria ortostática. Consiste em dosear a relação proteínas/creatinina na primeira urina da manhã obtida em casa em decúbito, antes de se levantar (tendo esvaziado a bexiga ao deitar na noite anterior) e repetir o exame na amostra de urina após umas horas em posição de pé. Um valor normal na amostra de urina em decúbito e alterado após horas em ortostatismo indica proteinúria ortostática, que requer controlo anual.

Se a relação proteínas/creatinina urinária persiste alterada nas duas amostras de urina considera-se a proteinúria persistente, que requer uma avaliação rigorosa com o objetivo de identificar a causa. Começar com o exame do sedimento urinário procurando sinais de lesão glomerular ou do parênquima renal como a hematúria e a piúria. Quantificar a proteinúria de 24 horas, determinar a creatinina, ureia e iões séricos como exames complementares básicos. Só depois, em função destes resultados, do quadro clínico e da evolução, se prossegue a investigação: proteínas totais, proteinograma, imunoglobulinas, complementos, teste de infeção estreptocócica, anticorpos anti-nucleares (ANA), serologias de hepatite $\mathrm{B}, \mathrm{C}$ e $\mathrm{VIH}$, assim como ecografia renal. 
A decisão de realizar biópsia renal deverá ser do nefrologista pediátrico.

\subsubsection{Síndrome nefrítico}

O síndrome nefrítico é um conjunto de manifestações clínicas causado por um início agudo de lesão e inflamação glomerular com diminuição da filtração glomerular, retenção hidrossalina (hipertensão arterial, edemas periféricos e nos casos mais graves insuficiência cardíaca congestiva e edema pulmonar), hematúria (microscópica ou macroscópica) e insuficiência renal aguda (oligúria, elevação da ureia e creatinina em 25 a 30\%). A proteinúria é em regra discreta $(<1 \mathrm{~g} / \mathrm{L})$.

A etiologia pós-infeciosa é a mais frequente, mas pode ser secundário a doenças primárias glomerulares (como a nefropatia a lgA) ou doenças sistémicas (como lúpus eritematoso sistémico, púrpura de Henoch-Schönlein, poliarterite nodosa e outras vasculites, síndromes como hemolítico-urémico e Goodpasture) e doenças renais como a nefrite tubulo-intersticial e nefrite pós-radiação.

Na criança, o síndrome nefrítico agudo apresenta-se com hematúria, edemas ou hipertensão, mas formas de apresentação sub-clínica são comuns. Raramente, surge como glomerulonefrite rapidamente progressiva.

Factos a reter na avaliação inicial na criança com sindrome nefrítico agudo:

- Análise de urina: para confirmar hematúria de origem glomerular (eritrócitos dismórficos no sedimento), cilindros eritrócitarios e quantificar proteinúria (relação proteínas/creatinina urinária na primeira urina da manhã).
- Bacteriologia e anticorpos anti-estreptocócicos: pesquisa de Ags estreptocócicos na orofaringe (teste rápido), doseamento do título de antiestreptolisina O (TASO), anti-DNAse B.

- Imunologia: estudo do complemento (C3, C1q e C4), anticorpo anticitoplasma neutrófilo (ANCA), anticorpos antinucleares (ANA), anticorpos anti-dsDNA e anti-membrana basal glomerular.

- Função renal (creatinina e ureia elevadas na insuficiência renal aguda), ionograma (alterações hidro-eletrolíticas - hiperkaliémia), cálcio e fósforo, gasimetria e proteínas plasmáticas.

- Hematologia: hemograma com esfregaço do sangue periférico.

- Radiografia do tórax, ecografia renal e cardíaca.

As causas mais comuns de síndrome nefrítico na idade pediátrica são a glomerulonefrite aguda pós-infeciosa, a nefropatia a IgA e nefrite da púrpura de Henoch-Schönlein (PHS).

\section{Factos a reter nas características \\ clínicas de uma criança \\ com síndrome nefrítico agudo não sugestivos de glomerulonefrite aguda pós-estreptocócica:}

- História familiar de doença glomerular.

- Idade da criança (<4 anos ou > 15 anos).

- História prévia de sintomas similares.

- Evidência de doença extra-renal.

- Evidência de doença aguda ou crónica não estreptocócica.

- Evidência de doença crónica renal. 


\subsubsection{Glomerulonefrite}

aguda pós-infeciosa

A glomerulonefrite aguda é uma doença renal com inflamação do glomérulo, secundária a um mecanismo imunológico. A maioria dos episódios de glomerulonefrite aguda está associada a um estado pós-infeccioso.

A etiologia da glomerulonefrite aguda pós-infecciosa (GNAPI) é múltipla: bacteriana (Streptococcus beta-hemolítico do grupo A EBHGA, Staphylococcus, Streptococcus pneumoniae...), vírica (Epstein-Barr, vírus da hepatite $B$, influenzae, coxsackie $B$, herpes...), ricketsias, fungos e parasitas (schistosoma, plasmodium, toxoplasma...). A etiologia vírica tem aumentado de frequência. O EBHGA é o agente mais implicado sendo responsável pela forma clássica de glome-

\section{rulonefrite aguda pós-estreptocócica.}

A incidência da GNAPI é desconhecida, porque numa percentagem elevada a doença é ligeira ou assintomática (estima-se que a relação entre pacientes assintomáticos e sintomáticos seja de 2:1 a $3: 1)$.

A prevalência da GNAPI relaciona-se estreitamente com as condições sociais e económicas das sociedades. Nos países industrializados, pela melhoria das condições de vida e, provavelmente, por fatores relacionados com a prevalência e virulência dos próprios agentes infeciosos, assistiu-se nas últimas duas a três décadas a um declínio aparente da doença, mas pode estar a haver um discreto aumento nos últimos anos dos casos de GNAPI em idade pediátrica.

Existem hoje provas convincentes que nos permitem afirmar que as lesões glomerulares existentes na glomerulonefrite aguda são motivadas por um mecanismo imunológico. Um estímulo antigénico vai ativar mecanismos imunes (ativação de células imunocompetentes e produção de anticorpos pelos linfócitos B), formação de imunocomplexos, ativação do complemento (podem estar envolvidos elementos da cascata do complemento e sistemas complementares de regulação), surgindo a infiltração de leucócitos e a proliferação de células glomerulares e finalmente libertação de mediadores. São sobretudo complexos circulantes de antigénio e anticorpo que ficam retidos no filtro glomerular, dado o seu elevado peso molecular e dimensões. Daqui, resulta a ativação do complemento e, localmente, uma reação de tipo inflamatório com infiltração leucocitária, lesão do endotélio capilar com aderência plaquetária, deposição de fibrina e destruição tecidular. Este mecanismo parece ser responsável pela maioria das glomerulonefrites pós-infeciosas.

A gravidade e a progressão para lesão crónica dependem da duração e quantidade da exposição ao antigénio e da capacidade do hospedeiro para remover os imunocomplexos depositados.

Se a localização dos imunocomplexos circulantes ocorrer no mesângio vai originar uma proteinúria ligeira e hematúria; se for na membrana basal glomerular, origina proteinúria maciça. As alterações estruturais renais vão desde a proliferação celular (endotelial, mesangial e epitelial), depósitos de imunocomplexos no lado endotelial ou epitelial da membrana basal, intramembranosos ou no mesângio até hialinização ou esclerose (lesão irreversível).

O diagnóstico diferencial faz-se entre situações que cursam com hematúria e nefrite: glomerulonefrite membranoproliferativa (suspeita se os níveis de C3 forem persistentemente baixos após seis semanas de evolução); nefrite da PHS (valor 
de C3 e C4 normais; rash purpúrico característico); nefropatia de IgA (suspeita se episódios recorrentes de hematúria macroscópica associados a infeção respiratória); outras situações menos comuns (como a nefrite lúpica, recorrência e/ou recaída de glomerulonefrite crónica, de entre outras).

\subsection{Glomerulonefrite} aguda pós-estreptocócica

Vamos focar algumas particularidades da glomerulonefrite mais frequente na criança, a glomerulonefrite aguda pós-estreptocócica (GNAPE). Esta forma de glomerulonefrite surge sobretudo dos três aos 14 anos, com um pico de incidência entre os cinco e os oito anos e abaixo dos dois anos é inferior a $5 \%$ dos casos. A incidência é superior no sexo masculino (2:1).

Os sintomas clínicos surgem habitualmente

\section{8 a 21 dias (mais frequente 10 a 14 dias)} após infeção estreptocócica das vias respiratórias superiores (amigdalite) ou 3 a 6 semanas após uma infeção da pele (impétigo). Aqui, o intervalo é mais difícil de determinar. Este período de latência, antes do aparecimento dos sintomas de doença renal, é mais uma prova da presença de um mecanismo imunológico.

Surge habitualmente como doença esporádica, mas pode ocorrer em epidemias (sobretudo nos países subdesenvolvidos). Os casos epidémicos têm melhor prognóstico do que a doença esporádica.

O início do processo de nefrite ocorre quando o hospedeiro susceptível desenvolve anticorpos contra os antigénios nefritogénicos, as proteínas $M$ de alguns EBHGA (piodermites M 47, 49, 55, 57 e infeção faríngea M 1, 2, 4 e 12), endoestreptosina, o recetor da plasmina associado a nefrite, proteínas catiónicas e estreptoquinase. A cascata inflamatória que provoca lesão renal pode ser desencadeada por: 1) ativação do plasminogéneo em plasmina, pela estreptoquinase ou proteínas estreptocócicas similares; 2) deposição nos glomérulos de imunocomplexo antigénio/anticorpo pré-formados; ou por 3) ligação de anticorpos pré-formados contra estreptococos a proteínas renais estruturalmente homólogas.

Vai haver uma reação cruzada entre componentes glomerulares e antigénios estreptocócicos, a formação de anticorpos contra laminina, colagénio, elementos do mesângio, membrana basal glomerular, com formação de imunocomplexos circulantes e in situ e ativação do complemento.

As infeções faríngeas são mais frequentes no inverno e primavera e as infeções cutâneas no verão e outono. Somente 10 a 15\% dos doentes infetados com estirpes nefritogénicas do EBHGA desenvolvem GNAPE, sugerindo que fatores do hospedeiro podem ser importantes. O risco de nefrite varia com o serotipo do estreptococo. A ocorrência simultânea de febre reumática e glomerulonefrite aguda, embora descrita, é extremamente rara.

\section{Formas de apresentação da GNAPE:}

\section{Síndrome nefrítico agudo:}

A hematúria glomerular está presente em 100\% dos casos (em cerca de 1/3 é macroscópica, e resolve-se em dias). A hematúria microcópica pode persistir um ano ou mais e agravar-se com infeções respiratórias ou exercício. Os edemas estão presentes em 90\% e a hipertensão em 60 a $80 \%$ dos doentes. A oligúria (50\%) associa-se a um grau variável de insuficiência renal aguda (25 a 
$30 \%$ ). A proteinúria geralmente é inferior a $1 \mathrm{~g} / \mathrm{L}$. Complicações raras como urémia (necessidade de diálise $<5 \%$ ), insuficiência cardíaca congestiva $(<5 \%)$ e encefalopatia hipertensiva (excecional) estão igualmente descritas.

\section{Sub-clínica ( 50\%):}

Hematúria microscópica associada a redução de C3. A tensão arterial pode ser normal ou elevada. Nos surtos epidémicos é a forma de apresentação mais frequente.

\section{Síndrome nefrótico (<4\%):}

Proteinúria intensa é pouco frequente em idade pediátrica, sendo uma apresentação mais frequente em adultos.

\section{GMN rapidamente progressiva ( $<2 \%)$ :}

Azotémia progressiva e oligúria. Biópsia renal com proliferação extracapilar, com crescentes na microscopia ótica.

Nas formas mais graves de glomerulonefrite aguda, a retenção de água e de eletrólitos pode originar insuficiência cardíaca, hiperkaliémia, acidose, hiperfosfatémia e hipocalcémia. A retenção de água e de eletrólitos, por um lado, e de produtos azotados por outro, podem motivar hipertensão e, na ausência de tratamento, o estado mais temido: a encefalopatia hipertensiva com convulsões, edema cerebral, coma e morte.

Na grande maioria dos casos a evolução dos doentes é bem mais moderada, o que não justifica banalizarmos os casos de glomerulonefrite aguda. Todos necessitam de vigilância clínica regular, não só durante a fase aguda, como depois.
Dado que dois sinais clinicos (hipertensão e oligúria) vão condicionar todas as medidas terapêuticas, é absolutamente necessário, numa criança com suspeita glomerulonefrite aguda, saber se eles estão presentes ou não.

A determinação da tensão arterial só pode ser bem efetuada numa criança se a braçadeira cobrir cerca de 2/3 do braço. De contrário, os valores encontrados são falsos; é pois necessário dispor de braçadeira com medidas (5 e $12 \mathrm{~cm}$ ) adequadas às dimensões do doente.

A forma mais fiel e mais prática de saber da existência de uma diminuição importante da diurese é a determinação do peso da criança em dias seguidos e até duas vezes por dia.

Perante um doente com uma sintomatologia sugestiva de glomerulonefrite aguda, a investigação inicial deve incluir análise sumária de urina, pesquisa de focos de infeção estreptocócica, estudo do complemento e avaliação da função renal.

\section{A análise de urina com sedimento urinário} indica-nos em todos os casos a presença de hematúria e, frequentemente, cilindrúria eritrocitária e proteinúria. A pesquisa da proteinúria (relação Prot/Creat, na primeira urina da manhã) é positiva em cerca de $97 \%$ dos casos. Durante a fase aguda da doença, a urémia está aumentada (superior a $6 \mathrm{mmol} / \mathrm{L})$ em cerca de $90 \%$ dos doentes. Com estes três exames, com a clínica e com a noção exata da tensão arterial e das variações do peso da criança que refletem a diurese, consegue-se na maioria dos casos fazer o diagnóstico e tratar adequadamente.

Dois outros exames são importantes (sobretudo no diagnóstico diferencial com o síndrome nefrótico): 1) Doseamento da globulina beta-1-C ou terceiro componente do 
complemento (C3) que se encontrará baixo durante a fase aguda da glomerulonefrite aguda pós-estreptocócica. O resultado é normal no síndrome nefrótico idiopático. No estudo do complemento ( $\mathrm{C} 3, \mathrm{C} 4, \mathrm{CH} 50)$, o valor de $\mathrm{C} 3$ está diminuído em mais de $90 \%$ dos casos nas duas primeiras semanas de doença e o C4 está quase sempre normal (baixa inicial discreta e transitória). 2) Doseamento das proteínas séricas e em particular da albuminémia que, na grande maioria dos casos de glomerulonefrite aguda (cerca de 93\%) estará normal (acima de 35 g/L), enquanto se verificará uma hipoalbuminémia no síndrome nefrótico.

A pesquisa de infeção estreptocócica é efetuada através do doseamento do TASO, anti-DNAse B e cultura do exsudato faringeo ou da pele; a elevação dos títulos de anticorpos contra antigénios estreptocócicos, em duas determinações com 2 a 3 semanas de intervalo, é mais fidedigna para o diagnóstico do que um TASO isolado $\geq 250 \mathrm{U}$. Dos anticorpos anti-estreptococos: o TASO eleva-se na primeira semana (máximo 2 a 4 semanas) e normaliza em 6 a 12 meses. Nas infeções cutâneas eleva-se apenas o anti-DNAse B (eleva-se de forma mais rápida).

As alterações da função renal (creatinina, ureia), de eletrólitos (hiperkaliémia), cálcio e fósforo, gasimetria correlacionam-se diretamente com a gravidade da lesão renal. A sobrecarga hidrossalina pode ser desproporcionada ao nível de insuficiência renal aguda (IRA). O hemograma, proteínas plasmáticas e perfil lipídico devem também fazer parte da investigação. Ecografia renal, radiografia do torax e ecografia cardíaca devem fazer parte da investigação das formas de apresentação mais graves.
A realização de biópsia renal está reservada para os casos cuja apresentação clínica, investigação laboratorial ou evolução seja atípica.

\section{Tratamento:}

O tratamento na fase aguda influencia consideravelmente a morbilidade e mortalidade precoce da doença. Deve incluir medidas de suporte (tratamento da infeção estreptocócica, repouso, restrição de líquidos e sal) e outras dirigidas a potenciais complicações como a hipertensão arterial com dieta sem adição de sal, diuréticos de ansa (furosemida), bloqueadores dos canais de cálcio (nifedipina).

Na glomerulonefrite rapidamente progressiva está indicada corticoterapia (iniciar com "pulsos" de metilprednisona) e imunossupressores.

As resinas permutadoras de iões estão indicadas na hiperkaliémia isolada. Se houver associação de urémia progressiva e/ou congestão circulatória ou persistência de hiperkaliémia, está indicada diálise.

A maioria dos casos de glomerulonefrite aguda apresenta uma evolução benigna. Nestes casos, a atitude mais importante é avaliar cuidadosamente a clínica. Se a criança não apresentar uma sintomatologia intensa e se, sobretudo, não houver hipertensão nem oligúria, após a confirmação laboratorial do diagnóstico poderá ser seguida ambulatoriamente. Para eliminar possíveis focos de infeção estreptocócica, deverá administrar-se amoxicilina (50 mg/kg/dia dividida em três tomas) durante 10 dias ou penicilina benzatínica $G$ intramuscular dose única 600 $000 \mathrm{U}$ antes dos cinco anos; e 1200000 após os cinco anos. A criança deve permanecer em casa durante a fase aguda, com dieta sem adição de 
sal, reduzindo a atividade mas não é necessário um repouso estrito. O peso deverá ser avaliado semanalmente, bem como a tensão arterial, o que implica um controlo clínico.

\section{Quando internar na glomerulonefrite} aguda pós-estreptocócica:

Está indicada hospitalização sempre que a criança apresentar: hipertensão arterial, oligúria, sinais clínicos graves (edema generalizado, creatinina sérica elevada, alterações eletrolíticas, convulsões, alterações do ritmo cardíaco) ou qualquer outro sinal que indique tratar-se de uma forma não benigna. A mortalidade na fase aguda é excecional e o prognóstico é favorável para a maioria das crianças.

\section{Evolução:}

A resolução das manifestações clínicas, em geral, é rápida. O edema resolve em cinco a dez dias e a tensão arterial normaliza habitualmente após duas a três semanas. A hematúria macroscópica desaparece em uma a três semanas e a microscópica após 12 meses; a proteinúria nos primeiros dois a três meses. O valor de C3 normaliza após oito a dez semanas.

As principais complicações com influência na mortalidade são: IRA com necessidade de diálise (<5\%); insuficiência cardíaca, edema agudo do pulmão (raro) e encefalopatia hipertensiva (excecional).

Uma vez passada a fase aguda (desaparecimento dos sintomas clínicos, normalização da ureia plasmática e do (3) o doente deverá consultar regularmente, por exemplo uma vez por mês durante os primeiros três meses, e a seguir cada seis meses. Nestas consultas deverão ser executados dois exames: proteinúria e sedimento urinário. Uma hematúria microscópica pode persistir durante anos sem que isso implique um prognóstico mais reservado ou qualquer forma de tratamento.

A persistência de hematúria macroscópica mais de três semanas, de hipertensão ou de proteinúria significativa para além de seis meses, deve fazer suspeitar uma evolução menos favorável. A criança deverá ser enviada a uma consulta de nefrologia pediátrica afim de proceder ao exame mais detalhado da função renal e eventual biópsia renal.

Segundos episódios de GNAPE são raros. Isto pode dever-se à persistência de anticorpos para os antigénios estreptocócicos associados a nefrite.

\section{Prognóstico:}

O prognóstico na fase aguda é excelente, com evolução favorável e completa resolução em 95\% casos. Cerca de $4 \%$ curam com um ligeiro défice da função renal. A mortalidade na fase aguda é muito rara (pode ocorrer por hiperkaliémia, edema do pulmão...). Estudos de seguimento longos (10 a 20 anos), revelam a presença de alterações urinárias (proteinúria e hematúria microscópica) em 5 a 20\%. Considerar a possibilidade de doença renal crónica (<1\%) sempre que a hematúria e proteinúria persistam mais de um ano.

\subsubsection{Nefropatia IgA}

A nefropatia a IgA teve a primeira descrição em 1968 (Berger). Pode surgir em qualquer idade, mas é mais comum na segunda e terceira 
décadas de vida, sendo rara abaixo dos três anos. Tem predomínio no sexo masculino (65\%) e é mais frequente na raça caucasiana. A forma de apresentação clínica mais frequente é o aparecimento de hematúria macroscópica, muitas vezes precepitada por uma infeção respiratória alta. O intervalo entre a infeção precipitante e o início da hematúria macroscópica é de um a dois dias, em contraste com o intervalo médio de duas semanas entre a infeção estreptocócica e o início da GNAPE. Na apresentação clínica, além da hematúria macroscópica, pode surgir como: hematúria microscópica assintomática e proteinúria; sindrome nefrítico agudo; síndrome nefrótico (<10\%); síndrome nefrótico-nefrítico e mais raramente glomerulonefrite rapidamente progressiva com crescentes ( $>50 \%$ dos glomérulos) e insuficiência renal aguda (necrose tubular com cilindros hemáticos intratubulares e glomérulos pouco alterados).

A patogenia é desconhecida, mas está demonstrado que os depósitos de IgA no mesângio pertencem à subclasse IgA1. A IgA1 é anómala (defeito de glicosilação), induz formação de auto-anticorpos e imunocomplexos circulantes com deposição no mesângio (proliferação celular, libertação de mediadores inflamatórios, complementos). A lesão anatomo-patológica mais frequente é a glomerulonefrite proliferativa mesangial (hipercelularidade mesangial e aumento da matriz mesangial), mas as lesões podem variar de lesões mínimas a proliferação endocapilar/extracapilar generalizada.

O diagnóstico de nefropatia a IgA só pode ser feito, com certeza, demonstrando os depósitos granulares de IgA predominantes no mesângio glomerular. Em menos de $20 \%$ das crianças com nefropatia a $\lg$ A existe elevação sérica da $\lg A$, sugerindo o diagnóstico. No entanto, esta elevação sérica da IgA não é suficiente para o diagnóstico, que deve ser feito com biópsia renal. Como a apresentação clínica não permite o diagnóstico é importante dosear o C3, TASO e anticorpos anti-nucleares para excluir outras causas.

A semelhança histológica entre a nefropatia de IgA e a nefrite da PHS sugere uma relação patogénica estreita entre estas duas entidades.

O prognóstico da nefropatia de IgA na criança é melhor do que nos adultos.

Factos a reter na Nefropatia de IgA:

- Em regra apresenta-se com hematúria macroscópica um a dois dias após uma infeção respiratória alta.

- A maioria das crianças afetada tem hematúria microscópica persistente.

- O prognóstico é melhor do que nos adultos. As crianças mais jovens e as que não apresentam hematúria macroscópica têm melhor prognóstico a longo prazo.

\subsubsection{Síndrome nefrótico}

O síndrome nefrótico (SN) é a manifestação clínica de alterações bioquímicas produzidas por lesão glomerular que tem como ponto fundamental a alteração da permeabilidade da parede capilar glomerular, dando origem a uma proteinúria intensa com hipoalbuminémia. As manifestações clínicas são devidas a esta hipoalbuminémia.

O SN idiopático é aquele que não é secundário a nenhuma doença causal, sendo ele a única manifestação de doença, devendo excluir-se deste o SN iniciado no primeiro ano de vida, cujas características etiopatogénicas e 
evolução clínica são diferentes e lhe conferem uma entidade especial. A importância desta diferença tem implicação no tratamento a realizar no SN secundário e no SN no primeiro ano de vida.

\section{Definição:}

O SN é caracterizado por hipoalbuminémia, proteinúria maciça e edema. A hipercolesterolémia que acompanha habitualmente o SN, não é constante. O SN idiopático define-se como uma doença glomerular primária com proteinúria> $40 \mathrm{mg} / \mathrm{m}^{2} /$ hora, albuminémia $<2,5 \mathrm{~g} / \mathrm{dL}$ e edema generalizado. A sua incidência é 17,5 a 20 novos casos por ano e por milhão de crianças entre os 0 e os 14 anos de idade.

O SN idiopático atinge, em regra, crianças de um a seis anos, iniciando-se por edema, progressivamente mais intenso, acompanhados de oligúria e aumento excessivo de peso. Não há hematúria macroscópia e a tensão arterial é normal. Há proteinúria maciça e hipoalbuminémia. A hipercolesterolémia e hipertrigliceridémia são frequentes.

Antes do emprego dos antibióticos, o SN idiopático (que constitui $85 \%$ dos casos em Pediatria) era uma doença grave com uma taxa de mortalidade de cerca de $67 \%$. Estas crianças morriam, na maior parte das vezes de infeção (por exemplo peritonite pneumocócica). Curiosamente, já nesta época, 33\% destas crianças entravam espontanemante em remissão após o primeiro episódio. A utilização dos corticoides reduziu a mortalidade a cerca de 5\%.

Apesar dos resultados obtidos com os corticoides, ainda subsistem muitos pontos de interrogação no que se refere aos mecanismos imunológicos que estão na base do SN idiopático e ao modo de resposta ao tratamento. Por outro lado, a administração de corticoides de uma forma prolongada implica riscos: baixa estatura, alterações da face, acne, osteoporose, estrias cutâneas, suscetibilidade às infeções.

\section{Factos a reter no síndrome \\ nefrótico idiopático:}

- Mais comum no sexo masculino, nos árabes e indianos.

- Pico de incidência entre os dois e os cinco anos.

- A lesão histológica mais comum é a doença de lesões mínimas.

- Evidências indiretas implicam, na sua etiologia, componentes genéticos.

\section{Fisiopatologia do síndrome sefrótico:}

Na sequência dum processo imunológico cuja natureza não é ainda perfeitamente conhecida, origina-se uma lesão da membrana glomerular aumentando-Ihe a permeabilidade. Este aumento de permeabilidade origina uma perda de proteínas na urina. Esta albuminúria maciça e repetida durante alguns dias leva a uma hipoalbuminémia e, secundariamente, a uma diminuição da pressão oncótica e a uma diminuição do volume plasmático circulante. Daqui resultam três fenómenos:

1. Como resultado duma hipovolémia, há diminuição da filtração glomerular, portanto uma insuficiência renal pré-renal mais ou menos grave.

2. A própria hipovolémia (contração do volume extracelular) tem uma ação direta no tubo proximal aumentando a reabsorção do sódio. 
3. A hipovolémia contribui para uma secreção exagerada de aldosterona, o que favorece a reabsorção de sódio ao nível do rim. Este triplo mecanismo contribui para a formação de edema. Se o doente não for tratado, ao edema segue-se a formação de ascite e acumulação de líquido na pleura e no pericárdio - anasarca.

O metabolismo dos lípidos também se encontra alterado no síndrome nefrótico, embora a exata natureza desta alteração não esteja ainda completamente esclarecida.

Factos a reter na hipovolémia no síndrome nefrótico idiopático:

- A criança com síndrome nefrótico está em risco significativo de hipovolémia.

- Dor abdominal na criança com SN é um sintoma de hipovolémia ou peritonite.

- A avaliação clínica pode ser difícil. Sinais importantes de hipovolémia significativa incluem extremidades frias, atraso da velocidade de reperfusão capilar e redução da pressão venosa jugular.

Factos a reter na investigação laboratorial do síndrome nefrótico idiopático:

- Na urina: análise de urina e sedimento urinário. Quantificar a proteinúria (relação proteínas/creatinina urinária na primeira urina da manhã). Colheita de urina de 12 ou 24 horas para quantificar proteinúria. Sódio urinário quando se suspeita de hipovolémia.

- No plasma: ureia, creatinina, ionograma, cálcio e fósforo, albumina, proteínas totais, albumina e globulinas, colesterol, triglicerídeos, complementos (C3 e C4) e IgG. Hemograma.

Definições referentes à resposta ao tratamento corticoide:

1. Remissão: quando sem proteinúria (< $4 \mathrm{mg} / \mathrm{m}^{2} / \mathrm{h}$ ora ou índice proteína / creatinina urinária $<20$ ) ou tira reativa negativa / indícios durante cinco dias consecutivos.

- Remissão parcial: normaliza a albuminémia (> 3g/L) e persiste proteinúria não nefrótica (4 a 40 mg/m²/hora).

- Remissão total: sem proteinúria e albuminémia normal.

2. Recaída (ou recidiva): proteinúria significativa (tira reativa $>++$ ) durante três dias consecutivos ou se apresenta edemas.

A resposta ao tratamento com corticoides, diferencia os seguintes tipos de SN:

- Corticossensíveis (CS): quando a resposta à prednisona, administrada segundo um protocolo, tem remissão completa do síndrome clínico e bioquímico. Segundo a evolução classificam-se:

Sem recaídas:

Sem recidivas após tratamento do episódio inicial (cerca de 25\%).

\section{Recaídas pouco frequentes:}

$<2$ recaídas nos 6 meses que seguem o primeiro tratamento ou $<4$ recaídas durante um período de 12 meses. 


\section{Recaídas múltiplas:}

Duas ou mais recaídas durante um período de 6 meses que segue o primeiro tratamento ou 4 ou mais recaídas durante um período de 12 meses.

- Corticodependentes (CD): apresentar 2 recaídas consecutivas ao reduzir a prednisona ou quando suspende o tratamento aparecer uma recaída nas 2 semanas seguintes.

- Corticorresistentes (CR): resistência aos corticoides (persiste o SN): ausência de remissão após 8 semanas de tratamento ou 4 semanas mais "pulsos" de metilprednisona.

\section{Biópsia renal:}

Entre os métodos de diagnóstico enunciados, a biópsia renal é aquele que fornece melhores indicações, embora não absolutas, quanto ao prognóstico. Não existe unanimidade nas indicações para biópsia renal. Na criança, o consenso é não realizar biópsia renal antes do tratamento com corticoides, já que a maioria são corticossensíveis (admitindo-se corresponder a lesões mínimas). A biópsia renal está indicada em determinadas situações:

- Idade <12 meses (síndrome nefrótico congénito e infantil).

- Idade> 16 anos (caraterísticas de síndrome nefrótico do adulto).

- Hipertensão presente.

- Hematúria persistente ou macroscópica.

- Compromisso da função renal que não responde à correção da hipovolémia.
- C3 ou C4 baixos.

- Sem resposta ao tratamento inicial com prednisona.

A biópsia renal está indicada também: no SN secundário a doença sistémica ou infeciosa, tratamento prolongado com anticalcineurínicos (Tacrolimus, Ciclosporina) e na evolução de corticossensíveis ou corticodependentes para corticorresistentes.

As lesões primárias glomerulares podem classificar-se do seguinte modo:

1. Lesões mínimas: os glomérulos são praticamente normais, assim como o parênquima renal. No SN da criança (idiopático) constituem cerca de 75\% das imagens observadas no microscópio ótico (Estudo Internacional de Doenças Renais na Criança - ISKDCencontrou lesões mínimas em 76\%). Esta taxa de lesões mínimas diminui a partir dos oito anos e sobretudo durante a adolescência. As crianças com lesões mínimas respondem, em geral, favoravelmente aos corticoides (85\% após três semanas de tratamento e 91\% após cinco semanas de tratamento). Na microscopia eletrónica, há alterações ultraestruturais nos podócitos. Por definição, nas lesões mínimas não há alterações na microscopia ótica. Pode haver em algumas biópsias hipercelularidade e espessamento da matriz mesangial (glomerulonefrite proliferativa mesangial) e na imunofluorescência 
depósitos de IgM, IgG e C3 (raros de $\lg A$ ). Os depósitos mais frequentes são os de IgM, objeto de discussão, quanto ao valor prognóstico e resposta ao tratamento.

2. Glomerulosclerose focal e segmentar: as lesões atingem apenas alguns glomérulos e apenas um segmento de cada glomérulo. Constituídas por proliferação celular e esclerose associada, estas lesões aparecem em cerca de $10 \%$ dos casos (aumento da percentagem na adolescência). Em regra resistente ao tratamento corticoide e evolução para insuficiência renal.

3. GN membrano-proliferativa (rara abaixo dos 8 anos, 11\% na adolescência).

4. GN membranosa (rara).

O prognóstico das formas 2 e 3

é particularnente reservado.

\section{Prognóstico do síndrome nefrótico}

idiopático na criança:

Cerca de $80 \%$ responde habitualmente com uma remissão ao tratamento com corticoides e $20 \%$ são desde logo resistentes. Dos $80 \%$ de casos que respondem favoravelmente, $20 \%$ evoluirão para a cura, 30\% farão recaídas raras e $30 \%$ farão recaídas frequentes. O grupo com mais problemas será constituído pelos resistentes aos corticoides, corticodependentes e pelos que apresentarão recaídas frequentes.

Nestes dois últimos grupos (em particular nos corticodependentes que necessitam de doses elevadas de corticoides para estar em remissão), têm algum risco, na evolução, de poder tornar-se, mais tarde, resistentes o que agravará o prognóstico final.

\section{Tratamento do síndrome nefrótico:}

1. Tratamento com corticoides: o corticoide a empregar será a prednisona ou prednisoIona. Inicialmente, administram-se 60mg/ $\mathrm{m}^{2} /$ dia durante 4 a 6 semanas. Este tratamento diário é, em geral, seguido duma remissão ao fim de uma a duas semanas. A dose diária de prednisona pode ser repartida dando $2 / 3$ de manhã e 1/3 à noite. Após este tratamento diário, no caso de remissão, o tratamento é continuado da seguinte forma: $40 \mathrm{mg} / \mathrm{m}^{2} /$ dias alternados (em toma única), até perfazer 4 a 6 semanas. Segue-se, redução progressiva em 6 a 12 semanas, até suspender a terapêutica, se a criança se mantiver em remissão, o que acontece na grande maioria dos casos.

2. Fase aguda: se a criança se apresenta com hipovolémia grave, colapso ou ascite, de tal forma importante que interfira com a mobilização do diafragma e com a ventilação pulmonar, o tratamento consistirá num expansor do plasma, por exemplo, albumina humana na dose máxima de 1g/ $\mathrm{kg}(5 \mathrm{ml} / \mathrm{kg}$ de solução a $20 \%)$ em perfusão endovenosa durante cerca de 2 horas. No meio da perfusão, administrar um diurético de ansa, furosemida (Lasix $\left.{ }^{R}\right)$. A finalidade deste tratamento será diminuir a ascite e melhorar temporariamente a proteinémia e, consequentemente, a volémia.

Factos a reter na avaliação e tratamento da hipovolémia no síndrome nefrótico:

- A criança com síndrome nefrótico requer uma avaliação cuidadosa e repetida do seu 
estado circulatório; se diagnosticada hipovolémia deve ser prontamente tratada.

- A administração de albumina não deve ser feita por rotina a todas as crianças em recidiva e pode ser perigosa na criança com síndrome nefrótico sem hipovolémia.

Deve ser ensinado aos pais da criança a forma de executar diariamente a determinação qualitativa da proteinúria com Albustix ${ }^{R}$ ou Combur ${ }^{R}$ na primeira micção da manhã. Além disso, a criança deve ser pesada semanalmente e controlada em consulta externa.

Resultados obtidos com método semi-quantitativo (Albustix ${ }^{R}$ ou Combur ${ }^{R}$ ):i) ausência de proteinúria - Albustix ${ }^{R}$ negativo ou vestígios; ii)proteinúria significativa - Albustix ${ }^{R}$ entre 2 e $4+$; iii) se Albustix $^{R}$ a $1+$, este resultado não é interpretável e deve ser repetido.

No caso de recaída, a criança seguirá um esquema semelhante com as mesmas doses de prednisona oral com uma única diferença: o tratamento diário não será mantido durante seis semanas, mas só até que se obtenham três dias seguidos sem albuminúria.

3. Tratamento dos casos corticodependentes ou com recidivas frequentes: nestes casos, quando há efeitos secundários dos corticoides para manter o SN em remissão, podem utilizar-se com algum êxito certas drogas imunosupressoras, nomeadamente a ciclofosfamida (Endoxan $\left.{ }^{R}\right)$. Se bem que eficazes, em especial nos casos com recidivas frequentes, a frequência e gravidade dos efeitos secundários (alopécia, cistite hemorrágica, neutropenia, susceptibilidade a infeções e, sobretudo, esterilidade definitiva) levam que se reconsidere a sua indicação nestas circunstâncias, face ao uso prolongado de corticoterapia (Prednisona ou Deflazacorte) em baixa dose em dias alternados.

Se o SN persiste corticodependente e há sinais evidentes de efeitos secundários dos corticoides, ponderar, após prévia biópsia renal, tratamento com imunossupressores como micofenolato de mofetil, ciclosporina ou tacrolimus.

Nos casos corticorresistentes, a biópsia renal é importante para defenir o prognóstico e para a orientação do tratamento, mas o prognóstico é reservado.

4. Antibióticos: dado que muitas infeções podem precipitar uma recaída, deve-se tratar energicamente toda a intercorrência com o antibiótico indicado. Não está provada a eficácia da antibioterapia profilática.

5. Conselhos particulares: O repouso é aconselhado na fase aguda com anasarca e dificuldade respiratória. A restrição de sódio está indicada enquanto persistir o edema e proteinúria significativa.

Factos a reter:

- O SN é um quadro clínico que consiste em proteinúria, +++ na tira-fita urinária (> 40mg/m²/hora), hipoalbuminémia $<2,5$ $\mathrm{g} / \mathrm{dL}$ e edema, com ou sem hipercolesterolémia. Na criança, o quadro clássico típico do SN é o de lesões mínimas. 
- Porque a maioria das crianças com SN de lesões mínimas responde ao tratamento com corticoides, o tratamento empírico das crianças com características clínicas clássicas de lesões mínimas é iniciado sem realizar uma biópsia renal.

\section{Leitura complementar}

Avner ED, Ed. Pediatric Nephrology. 6th Ed. Springer - Verlag Heidelberg; 2009. 